\title{
Correction to: Suitable site selection for transfer stations in a solid waste management system using analytical hierarchy process as a multi-criteria decision analysis: a case study in Azuay-Ecuador
}

\author{
Sandra L. Cobos-Mora ${ }^{1,2}$ [D . José Guamán-Aucapiña ${ }^{3}$ (D) . Jonathan Zúñiga-Ruiz ${ }^{4}$
}

(C) The Author(s) 2022

\section{Correction to: Environment, Development and Sustainability https://doi.org/10.1007/s10668-022-02134-8}

The article "Suitable site selection for transfer stations in a solid waste management system using analytical hierarchy process as a multi-criteria decision analysis: a case study in Azuay-Ecuador ", written by Sandra L. Cobos-Mora, José Guamán-Aucapiña, Jonathan Zúñiga-Ruiz, was originally published electronically on the publisher's internet portal on 21 January 2022 without open access. With the author(s)' decision to opt for Open Choice, the copyright of the article changed on 2nd February 2022 to (c) The Author(s) 2022 and the article is forthwith distributed under a Creative Commons Attribution 4.0 International License, which permits use, sharing, adaptation, distribution and reproduction in any medium or format, as long as you give appropriate credit to the original author(s) and the source, provide a link to the Creative Commons licence, and indicate if changes were made. The images or other third party material in this article are included in the article's Creative Commons licence, unless indicated otherwise in a credit line to the material. If

The original article can be found online at https://doi.org/10.1007/s10668-022-02134-8.

Sandra L. Cobos-Mora

zhandry_cobos@yahoo.com; scobosm@ucacue.edu.ec

José Guamán-Aucapiña

jo_gu1994@hotmail.com

Jonathan Zúñiga-Ruiz

jonathan.m.z.r@hotmail.com

1 Research, Innovation and Technology Transfer Center (CIITT), Civil Engineer Career, Urban and Earth Data Science Research Group, and City, Environment, and Technology Research Group, Universidad Católica de Cuenca, Ricaurte Bibín street, Ricaurte parish, Cuenca canton - Ecuador, 010107 Cuenca, Ecuador

2 Department of Physical Geography and Regional Geographical Analysis, University of Sevilla, Doña María De Padilla, Sevilla, Spain

3 Civil Engineering, Universidad Católica de Cuenca, Cuenca, Ecuador

4 Environmental Engineering, Universidad Católica de Cuenca, Cuenca, Ecuador 
material is not included in the article's Creative Commons licence and your intended use is not permitted by statutory regulation or exceeds the permitted use, you will need to obtain permission directly from the copyright holder. To view a copy of this licence, visit http:// creativecommons.org/licenses/by/4.0/.

Open Access This article is licensed under a Creative Commons Attribution 4.0 International License, which permits use, sharing, adaptation, distribution and reproduction in any medium or format, as long as you give appropriate credit to the original author(s) and the source, provide a link to the Creative Commons licence, and indicate if changes were made. The images or other third party material in this article are included in the article's Creative Commons licence, unless indicated otherwise in a credit line to the material. If material is not included in the article's Creative Commons licence and your intended use is not permitted by statutory regulation or exceeds the permitted use, you will need to obtain permission directly from the copyright holder. To view a copy of this licence, visit http://creativecommons.org/licenses/by/4.0/.

Publisher's Note Springer Nature remains neutral with regard to jurisdictional claims in published maps and institutional affiliations. 